\title{
PENERAPAN HYGIENE SANITASI PENGELOLAAN MAKANAN DAN PENGETAHUAN PENJAMAH MAKANAN
}

\author{
HYGIENE SANITATION FOOD MANAGEMENT AND FOOD CRITER KNOWLEDGE \\ ${ }^{1 *}$ Rina Fauziah, ${ }^{2}$ Suparmi \\ $1^{1 *}, 2$ Poltekkes Kemenkes Jambi
}

Kontak koresponden: fauziah_rina@gmail.com

\begin{abstract}
ABSTRAK
Hygiene sanitasi makanan merupakan upaya untuk mengendalikan faktor yang dapat menimbulkan gangguan kesehatan. Proses pengelolaan makanan perlu diperhatikan enam prinsip hygiene sanitasi makanan dan pengetahun penjamah makanan dalam pengolahan makanan. Penelitian ini bertujuan mengetahui gambaran hygiene dan sanitasi di Pondok Pesantren AlJauharen Kelurahan Tanjung Johor Kecamatan Pelayangan Kota Jambi tahun 2019. Penelitian ini merupakan penelitian deskriptif, menggunakan sampel enam prinsip hygiene sanitasi pengelolaan makanan dengan empat orang penjamah makanan. Instrumen yang digunakan dalam penelitian ini adalah checklist penerapan hygiene sanitasi pengelolaan makanan dan kuesioner untuk pengetahuan penajamah makanan. Hasil penelitian didapatkan bahwa kondisi penerapan hygiene sanitasi belum memenuhi syarat karena masih terdapat tempat penyimpanan bahan makanan, tempat pengolahan makanan, pengangkutan makanan dan penyimpanan makanan jadi yang beresiko terhadap kontaminasi dan pencemaran terhadap makanan. Tingkat Pengetahuan penjamah makanan dalam pengelolaan makanan masih rendah sehingga beresiko terhadap kualitas makanan yang akan diolah dan disajikan untuk santri. Berdasarkan penelitian dapat disimpulkan bahwa masih kurangnya penerapan hygiene sanitasi dan pengetahuan penjamah makanan dipondok pesantren. Oleh karena itu perlu adanya peningkatan terhadap. Penerapan hygiene sanitasi mengingat makanan merupakan media yang memungkinkan penularan penyakit melalui kontaminasi pekerja atau pun penyakit bawaan makanan.
\end{abstract}

Kata Kunci: hygiene sanitasi; pengelolaan makanan; pengetahuan penjamah makanan

\section{ABSTRACT}

Food sanitation hygiene is an effort to control factors that can cause health problems. The food management process needs to pay attention to the six principles of food sanitation hygiene and knowledge of food handlers in food processing. This study aims to determine the description of hygiene and sanitation in Pondok Pesantren Al-Jauharen, Tanjung Johor Village, Service District, Jambi City in 2019. This study is a descriptive study, using a sample of six principles of hygiene and sanitation in food management with four food handlers. The instruments used in this study were a checklist for the application of hygiene and sanitation in food management and a questionnaire for the knowledge of food handlers. The results of the study found that the conditions for implementing hygiene and sanitation did not meet the requirements because there were still places to store foodstuffs, places to process food, transport food and store ready-to-eat food which were at risk of contamination and contamination of food. The level of knowledge of food handlers in food management is still low so there is a risk to the quality of 
the food that will be processed and served to students. Based on the research, it can be concluded that there is still a lack of application of hygiene, sanitation and knowledge of food handlers in Islamic boarding schools. Therefore, it is necessary to increase the The application of hygiene and sanitation considering that food is a medium that allows disease transmission through worker contamination or foodborne diseases.

Keywords: sanitation hygiene; food management; food handler knowledge

\section{Pendahuluan}

Menurut Undang - undang Republik Indonesia Nomor 36 Tahun 2009 tentang Kesehatan, kesehatan adalah keadaan sehat, baik secara fisik, mental, spiritual maupun sosial yang memungkinkan setiap orang untuk hidup produktif secara sosial dan ekonomi (Presiden RI, 2009). Banyak hal yang dapat mempengaruhi kesehatan terutama makanan yang dikonsumsi setiap hari, makanan ialah salah satu kebutuhan primer manusia. Makanan yang sehat sangat dibutuhkan sebagai sumber energi dan menjaga tubuh agar tidak mudah sakit. Makanan yang sehat adalah makanan yang dapat menunjang aktivitas, pertumbuhan dan pemeliharaan tubuh (Rochmah, 2018). Makanan yang dikonsumsi hendaknya layak untuk dimakan dan tidak menimbulkan penyakit oleh sebab itu perlu dilakukan pengawasan terhadap pemilihan bahan baku, penyimpanan bahan makanan, pengolahan makanan, pengangkutan makanan, penyimpanan makanan, dan penyajian makanan (Candra, 2012). Pengawasan terhadap sanitasi makanan dimulai dari enam prinsip sanitasi, mulai dari proses pemilihan bahan makanan sampai proses penyajian, Dengan demikian makanan yang berkualitas baik akan terhindar dari bahaya yang diakibatkan oleh proses dan penyimpanan makanan yang tidak baik (Candra, 2012). Selain itu faktor lain yang cukup penting untuk menjamin hygiene sanitasi adalah makanan yang diolah oleh penjamah makanan harus memenuhi persyaratan sebagai seorang penjamah sehingga makanan yang diolah terjamin untuk dikosumsi (Syahrizal, 2017). Pengetahuan penjamah sangat penting dalam proses pengelolaan makanan agar makanan yang dihasilkan mempunyai kualitas yang bagus. Pengetahuan adalah hasil "tahu" dan ini terjadi setelah orang melakukan penginderaan terhadap suatu objek tertentu. Penginderaan terjadi melalui panca indera manusia, yakni: indera penglihatan, pendengaran, penciuman, rasa dan raba. Sebagian besar pengetahuan manusia diperoleh melalui mata dan telinga (Notoatmodjo, 2010).

Pondok pesantren merupakan salah satu tempat untuk medidik agar santri-santri menjadi orang yang berakhlak mulia dan memiliki kecerdasan yang tinggi. Santri-santri yang berada di pondok pesantren merupakan anak didik yang pada dasarnya sama saja dengan anak didik di sekolah-sekolah umum yang harus berkembang dan merupakan sumber daya yang menjadi generasi penerus pembangunan yang perlu mendapat perhatian khusus terutama kesehatan dan pertumbuhannya. Salah satu aspek yang mendukung hal tersebut adalah kebutuhan makanan yang sehat dan bersih. Berdasarkan data dari kementerian agama Provinsi Jambi tahun 2018 bahwa di Kota Jambi terdapat sepuluh buah pondok pesantren dengan jumlah sebanyak 6.203 santri untuk lebih jelas dapat di lihat pada tabel berikut : 
Tabel 1. Data Pondok Pesantren Se Kota Jambi

\begin{tabular}{|c|c|c|c|c|c|c|}
\hline \multirow{2}{*}{ No } & \multirow{2}{*}{ Pondok Pesantren } & \multirow{2}{*}{ Jml. Murid } & \multirow{2}{*}{ Jml. Guru } & \multicolumn{2}{|c|}{ Status Ponpes } & \multirow{2}{*}{ Ket. } \\
\hline & & & & Negeri & Swasta & \\
\hline 1 & Nurul Iman & 447 & 52 & - & Swasta & \multirow{2}{*}{2} \\
\hline 2 & Sa'adatuddaren & 823 & 50 & - & Swasta & \\
\hline 3 & Al-Jauharen & 409 & 40 & - & Swasta & \multirow{5}{*}{5} \\
\hline 4 & As'ad & 1.925 & 125 & - & Swasta & \\
\hline 5 & PKP Al-Hidayah & 965 & 73 & - & Swasta & \\
\hline 6 & Ma'had Al-Mubarok & 506 & 487 & - & Swasta & \\
\hline 7 & Darul Muhtadin & 331 & 27 & - & Swasta & \\
\hline 8 & Tq Arriyad & 225 & 9 & - & Swasta & 1 \\
\hline 9 & Mambaul Ulum & 380 & 49 & - & Swasta & \multirow{2}{*}{2} \\
\hline 10 & Ainul Yaqin & 160 & 17 & - & Swasta & \\
\hline 11 & Tahfidz Darul Hikmah & 32 & 4 & - & Swasta & 1 \\
\hline & Jumlah & 6.203 & 933 & & & \\
\hline
\end{tabular}

Sumber: (Kemenag Jambi, 2020)

Berdasarkan tabel, jumlah santri terbanyak ada pada pondok pesantren As'ad sebanyak 1.925 santri. Tetapi berdasarkan hasil survei terdapat pondok pesantren yang pengelolaan makanannya mempunyai risiko tinggi untuk terjadinya pencemaran makanan pengelolaan makanan yang dilakukan dalam satu kali sehari untuk tiga kali makan, sedangkan tempat penyimpanan makanan jadi tidak tersedia oleh karena itu tempat penyimpanan makanan jadi hanya disimpan didalam baskom dan diletakkan diatas lantai tanpa penutup, makanan yang tidak tertutup akan mudah basi dan mudah terkontaminasi oleh debu atau vektor lainnya. Hal lain yang beresiko terhadap pencemaran makanan yaitu tidak tersedianya tempat penyimpanan bahan makanan sehingga bahan makanan pokok dan bahan makanan mentah hanya diletakkan saja diatas lantai maka resiko terjadinya pencemaran makanan tinggi.

Hasil wawancara pada tanggal 31 Januari 2019 bahwa di pesantren Al-Jauharen memiliki 4 petugas penjamah makanan, bahan makanan dibeli di Pasar Angso Duo. Penjamah makanan pada saat melakukan pengelolaan makanan terlihat belum mempersiapkan diri untuk mengolah makanan dengan baik, yaitu tidak menggunakan celemek, pencucian tidak dengan air yang mengalir, pisau yang digunakan tidak dicuci dengan sabun pada saat mengolah makanan sehingga makanan yang diolah akan mudah terkontaminasi setelah di wawancarai ternyata penjamah makanan masih belum mengetahui cara pengelolaan makanan dengan baik. Berdasarkan latar belakang tersebut penulis tertarik untuk melakukan penelitian tentang "Penerapan hygiene sanitasi dan pengetahuan penjamah makanan di Pondok Pesantren AlJauharen Kelurahan Tanjung Johor Kecamatan Pelayangan Kota Jambi Tahun 2019".

Pentingnya penelitian ini dilakukan karena belum diketahuinya kondisi hygiene sanitasi dan pengetahuan pemakanan di pondok pesantren Al-Jauharen Kelurahan Tanjung Johor Kecamatan Pelayangan Kota Jambi tahun 2019. Penelitian lain yang bertujuan untuk mengetahui tindakan hygiene sanitasi yang sampelnya pedagang makanan jajanan di pinggir jalan, menghasilkan temuan bahwa mengindikasikan adanya risiko makanan yang dijajakan 
dapat tercemar kuman penyakit yang mengakibatkan penyakit bawaan makanan (Rahmayani, 2018). Penelitian lain yang hampir sama dengan penelitian ini beertujuan untuk meneliti perilaku penjamah makanan dalam menerapkan higiene sanitasi makanan di Pondok Pesantren Darul Falah V Kecamatan Diwek Kabupaten Jombang yang menghasilkan kesimpulan perilaku penjamah makanan sudah baik, namun masih ada beberapa aspek praktik hygiene makanan yang perlu ditingkatkan seperti pada personal hygiene. Pembedanya dari penelitian yang lain adalah tanggung jawab sampel dalam penelitian ini lebih banyak.

\section{Metode}

Jenis penelitian ini adalah deskriptif dengan pendekatan survei yaitu untuk menggambarkan penerapan hygiene sanitasi dan pengetahuan pengelolaan makanan di pondok pesantren Al-Jauharen (Arikunto, 2010). Lokasi penelitian dilakukan di pondok pesantren AlJauharen Kelurahan Tanjung Johor Kecamatan Pelayangan Kota Jambi.

Tabel 2. Kerangka Pikir

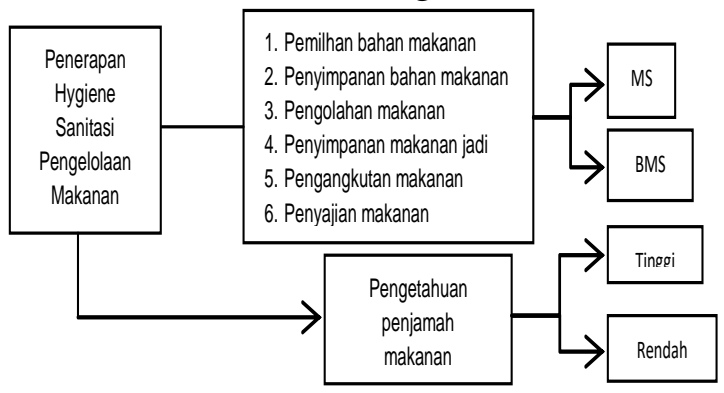

Penerapan hygiene sanitasi pengelolaan makanan dilaksanakannya prinsip-prinsip hygiene dan sanitasi makanan mulai dari pemilihan bahan makanan, penyimpanan bahan makanan, pengolahan makanan, penyimpanan makanan jadi, pengangkutan makanan, penyajian makanan untuk menjamin kebersihan dan keamanan agar tidak menimbulkan bahaya keracunan penyakit pada makanan (Rahmadhani \& Sumarmi, 2017). Pengetahuan yaitu segala sesuatu yang diketahui dan dipahami penjamah makanan dalam pengelolaan makanan di Pondok Pesantren Al-Jauharen. Populasi dan sampel dalam penelitian ini adalah penjamah makanan di Pondok pesantren Al-Jauhareni mulai dari Madrasyah Tsanawiyah dan Madrasyah Aliyah dengan 4 orang tenaga penjamah makanan. Instrumen yang digunakan dalam penelitian ini adalah checklist penerapan hygiene sanitasi pengelolaan makanan dan kuesioner untuk pengetahuan penajamah makanan.

\section{Tahapan Persiapan}

Menentukan topik dan mengurus surat pengantar untuk melakukan survei pendahuluan dan penelitian dari Poltekkes Kemenkes Jambi Jurusan Kesehatan Lingkungan kepada kepala pimpinan pondok pesantren Al-Jauharen, Kelurahan Tanjung Johor Kecamatan Pelayangan Kota Jambi.

\section{Tahapan Pelaksanaan}

1. Melakukan kunjungan dan survei ke pondok pesantren Al-Jauharen. 
2. Membuat checklist dan kuesioner

3. Melakukan penelitian menggunakan checklist hygiene sanitasi pengelolaan makanan dan kuesioner pengetahuan penjamah makanan dipondok pesantren.

4. Mengumpulkan/mengolah data yang telah di dapat dari hasil di lapangan.

5. Mendokumentasikan kondisi pengelolaan makanan.

\section{Analisis Data}

Data yang diperoleh dari hasil penelitian disajikan dalam bentuk tabel, kemudian dideskripsikan sesuai dengan hasil yang didapatkan dan dibandingkan dengan teori yang ada.

\section{Hasil}

Berdasarkan hasil penelitian didapat bahwa penerapan hygiene sanitasi pengelolaan makanan di pondok pesantren Al-Jauharen Kelurahan Tanjung Johor Kecamatan Pelayangan Kota Jambi dapat dilihat pada tabel berikut:

Tabel 3. Penerapan Hygiene Sanitasi Pengelolaan Makanan

\begin{tabular}{ll}
\hline \multicolumn{1}{c}{ Komponen } & \multicolumn{1}{c}{ Hasil } \\
\hline Pemilihan Bahan Makanan & Memenuhi syarat \\
\hline Penyimpanan Bahan Makanan & Belum memenuhi syarat \\
\hline Pengolahan Makanan & Belum memenuhi syarat \\
\hline Pengangkutan Makanan & Belum memenuhi syarat \\
\hline Penyimpanan makanan jadi & Belum memenuhi syarat \\
\hline Penyajian Makanan & Memenuhi syarat \\
\hline
\end{tabular}

Berdasarkan tabel di atas dari enam komponen pengelolaan makanan ada empat komponen yang belum memenuhi syarat yaitu penyimpanan bahan makanan, pengolahan makanan, pengangkutan makanan dan penyimpanan makanan jadi. Serta ada dua komponen yang memenuhi syarat yaitu pemilihan bahan makanan dan penyajian makanan.

Tabel 4. Pengetahuan Penjamah Makanan

\begin{tabular}{clcr}
\hline No & Pengetahuan & Jumlah & Persen $(\%)$ \\
\hline 1 & Tinggi & 1 & $84,62 \%$ \\
\hline 2 & Rendah & 3 & $15,38 \%$ \\
\hline & Total & 4 & 100 \\
\hline
\end{tabular}

\section{Pembahasan}

Dari tabel tersebut dapat diketahui bahwa penerapan hygiene. Sanitasi pengelolaan makanan ada dua komponen yang memenuhi persyaratan sedangkan empat komponen lainnya belum memenuhi syarat. Berdasarkan hasil penelitian di lokasi pemilihan bahan makanan yang dilakukan penjamah makanan memenuhi syarat karena bahan makanan dibeli ditempat yang resmi (angso duo) bahan makanan seperti sayur-sayuran dalam kondisi segar, tidak rusak dan tidak berubah bentuk. Bahan makanan seperti daging, susu, telur, ikan, dalam kondisi segar dan 
tidak rusak. Makanan kemasan mempunyai label dan merk, terdadaftar resmi, dan belum kadaluwarsa. Kualitas bahan makanan yang baik dapat dilihat melalui ciri-ciri fisik dan mutunya (Juherah \& Irmawati, 2019). Kualitas bahan makanan yang baik yaitu makanan yang terbebas dari pencemaran termasuk pencemaran kimia seperti pestisida dan juga kerusakan lainnya.

Penulis juga menemukan tempat penyimpanan bahan makanan yang tidak memenuhi syarat karena bahan makanan mentah seperti tempe yang hanya diletakan begitu saja diatas lantai tanpa menggunakan alas serta tempat penyimpanan bahan makanan kering seperti beras, kentang, kecap, garam, yang hanya letakan dilantai dan disudut dinding tanpa menggunakan alas dan tidak disimpan dalam lemari khusus serta suhu tempat penyimpanan bahan makanan lembab dan kondisi lantai sangat kotor. Apabila bahan makanan tidak disimpan dalam lemari khusus atau gudang akan mudah terkontaminasi oleh vektor seperti kecoa dan tikus. Berdasarkan sanitasi penyimpanan bahan makanan harus dilakukan dalam satu tempat khusus atau gudang dan lemari pendingin untuk makanan basah serta penyimpanan harus diatur dan disusun dengan baik agar memenuhi persyaratan hygiene sanitasi (Mokodongan et al., 2021).

Pengolahan makanan merupakan suatu proses perubahan bentuk dari bahan mentah menjadi makanan siap di konsumsi untuk menciptakan makanan yang baik, dalam pengolahan makanan harus memperhatikan kebersihan yaitu penjamah makanan yaitu penjamah makan yang bertugas untuk menjamah makanan dimulai dari persiapan bahan baku hingga penyajian makanan (Merdekawati \& Widiyanto, 2017). Kualitas makanan yang disajikan mempengaruhi pengetahuan sikap dan tidakan dari penjamah makanan untuk mencegah terjadinya pencemaran (Binaraesa et al., 2021). Pada saat dilokasi penelitian ditemukan lantai dapur tidak bersih masih banyak makanan yang tercecer di lantai, pada saat meracik bahan makanan penjamah tidak menggunakan sarung tangan serta pakaian penjamah makanan tidak rapi sehingga bahan makanan dapat tercemar secara fisik, pada saat mengolah makanan posisi kaki penjamah makanan dalam keadaan jongkok sebelum mengolah makanan penjamah makanan tidak mencuci tangan dengan sabun serta air yang mengalir, bahan makanan yang tidak dicuci dengan air yang mengalir dan hanya direndam saja didalam bak hal ini sejalan dengan penelitian.

Penulis juga menemukan tempat penyimpanan makanan jadi tidak disimpan didalam lemari penyimpanan khusus dan hanya diletakkan diatas lantai tanpa penutup, makanan masak merupakan bahan yang lunak dan sangat disukai bakteri, bakteri akan tumbuh dan berkembang dalam makanan yang mengandung protein dan kadar air yang tinggi seperti daging, ikan dan telur merupakan jenis makanan yang disukai bakteri apalagi pondok pesantren hanya mengolah makanan satu kali sehari untuk tiga kali makanan hal ini dapat menyebabkan resiko pencemaran dan kontaminasi yang sangat tinggi untuk di kosumsi (Yunita et al., 2014). Makanan akan cepat busuk atau basi jika penjamah makanan tidak memperhatikan suhu penyimpanan dan tempat penyimpanan makanan jadi (masak) (Binaraesa et al., 2021).

Pengangkutan makanan berperan dalam pencegahan terjadinya pencemaran makanan (Azizah \& Subagiyo, 2018). Proses pengangkutan makanan banyak pihak yang terkait mulai dari persiapan, pewadahan, orang, suhu dan kendaraan pengangkut itu sendiri. Karena makanan siap santap lebih rawan terhadap pencemaran sehingga perlu diperlakukan hati-hati. Saat penelitian 
pengangkutan makanan jadi tidak diangkut menggunakan pengangkutan yang higienis, tempat pengangkutan makanan tidak diangkut oleh penjamah makanan itu sendiri tetapi diangkut oleh santri, tempat pengangkutan makanan jadi dalam keadaan berkarat, tidak tertutup serta tidak tersedia jalan khusus untuk pengangkutan makanan sehingga pada saat kendaraan khusus terisi makanan kondisi makanan dapat menyebabkan kondensasi hal ini tidak sejalan dengan peraturan. Pengangkutan makanan jadi harus menggunakan kendaraan khusus dan harus selalu higienis, setiap jenis makanan jadi harus dalam keadaan tertutup tidak berkarat dan isi makanan tidak boleh penuh untuk menghindari terjadi uap makanan yang mencair (kondensasi).

Penjamah makanan dipondok pesantren memiliki peranan penting dalam pelaksanaan peningkatan sarana dan kualitas makanan (Syahrizal, 2017). Berdasarkan pengamatan penulis, diketahui seorang penjamah makanan sering kali tidak mementingkan cara pengelolaan makanan yang baik. Berdasarkan tabel dengan persentase $15,38 \%$ tidak mengetahui pentingnya cara pengelolaan makanan yang baik, berdasarkan penelitian yang dilakukan pengetahuan penjamah makanan tentang pengolahan hingga penyajian masih rendah, salah satu penyebab hal ini adalah kurangnya informasi tentang penerapan hygiene sanitasi pengolaan makanan yang benar agar tidak terjadinya kontaminasi oleh bakteri pathogen yang dapat mengganggu kesehatan.

Penulis menemukan pada saat dilokasi penjamah makanan tidak mencuci tangan sebelum dan sesudah mengolah makanan., semua bahan makanan yang akan diolah tidak dicuci hingga bersih begitupun peralatan masak yang akan digunakan. Terlihat pengetahuan penjamah sangat terbatas akan hal pengolahan makanan. Penjamah tidak memperhatikan hal-hal penting yang harus dilakukan saat mengolah makanan yakni dengan mencuci tangan. Tangan seharusnya selalu dicuci dengan sabun sebelum dan sesudah menangani makanan agar tidak terkontaminasi.

\section{Kesimpulan}

Dari hasil penelitian yang dilakukan di Pondok Pesantren Al-Jauharen dapat disimpulkan bahwa kondisi penerapan hygiene sanitasi di pondok pesantren Al-Jauharen belum memenuhi syarat karena masih terdapat tempat penyimpanan bahan makanan, tempat pengolahan makanan, pengangkutan makanan dan penyimpanan makanan jadi yang beresiko terhadap kontaminasi dan pencemaran terhadap makanan. Tingkat Pengetahuan penjamah makanan di Pondok Pesantren Al-Jauharen dalam pengelolaan makanan masih rendah sehingga beresiko terhadap kualitas makanan yang akan diolah dan disajikan untuk santri.

\section{Referensi}

Arikunto, S. (2010). Prosedur Penelitian Suatu Pendekatan Praktik. Rineka Cipta.

Azizah, Q. N., \& Subagiyo, A. (2018). Deskriptif Hygiene Sanitasi Pengelolaan Makanan di Lembaga Pemasyarakatan Kelas IIB Kabupaten Cilacap Tahun 2017. Buletin Keslingmas, 37(4). https://doi.org/10.31983/keslingmas.v37i4.3799

Binaraesa, N. N. P. C., Hidayat, I., \& Lestariningsih, M. (2021). Store Atmosphere Memoderasi Pengaruh Kualitas Makanan dan Kualitas Layanan Terhadap Kepuasan Konsumen (Studi pada Konsumen Moonk Cartil \& Cafe Surabaya). Jurnal Manajemen Pemasaran, 15(2). https://doi.org/10.9744/pemasaran.15.2.61-68 
Budiman Candra. (2012). Pengantar Kesehatan Lingkungan. EGC.

Jambi, K. P. (2020). Website Resmi Kanwil Kemenag Provinsi Jambi. https://jambi.kemenag.go.id/

Juherah, J., \& Irmawati, I. (2019). Perilaku Penjamah Makanan di Catering Anugerah dan Sekar Kota Makassar. Sulolipu: Media Komunikasi Sivitas Akademika Dan Masyarakat, 17(1). https://doi.org/10.32382/sulolipu.v17i1.675

Merdekawati, A. F., \& Widiyanto, T. (2017). Studi Deskriptif Hygiene Sanitasi Pengolahan Makanan di Instalasi Gizi RSJD Dr. Arif Zainudin Surakarta Tahun 2016. Buletin Keslingmas, 35(4). https://doi.org/10.31983/keslingmas.v35i4.1676

Mokodongan, A., Kadir, P. A., \& Pakaya, I. (2021). Sistem Penyimpanan Bahan Makanan Untuk Menjaga Kualitas Bahan Makanan di Kitchen TC Damhil UNG. Ideas: Jurnal Pendidikan, Sosial, Dan Budaya, 7(2). https://doi.org/10.32884/ideas.v7i2.372

Notoatmodjo. (2010). Kesehatan Masyarakat Ilmu dan Seni Jakarta. Rineka Cipta.

Presiden RI. (2009). Undang-undang Republik Indonesia No 36 tahun 2019 Tentang Kesehatan. In BMC Public Health.

Rahmadhani, D., \& Sumarmi, S. (2017). Gambaran Penerapan Prinsip Higiene Sanitasi Makanan Di PT Aerofood Indonesia, Tangerang, Banten. Amerta Nutrition, 1(4). https://doi.org/10.20473/amnt.v1i4.7141

Rahmayani, R. (2018). Hubungan pengetahuan, sikap dan tindakan hygiene sanitasi pedagang makanan jajanan di pinggir jalan. AcTion: Aceh Nutrition Journal, 3(2). https://doi.org/10.30867/action.v3i2.84

Rochmah, K. N. (2018). Pelaksanaan Usaha Kesehatan Sekolah (UKS) di SD 1 Bantul. Jurnal Pendidikan Guru Sekolah Dasar, 22(7).

Syahrizal, S. (2017). Hygiene Sanitasi Penjamah Makanan Terhadap Kandungan Escherichia Coli Diperalatan Makan Pada Warung Makan. AcTion: Aceh Nutrition Journal, 2(2). https://doi.org/10.30867/action.v2i2.67

Yunita, A., Wulandari, I., \& Fridintya, A. (2014). Gambaran Waktu Tunggu, Suhu, dan Total Bakteri Makanan Cair di RSUP Dr. Kariadi Semarang. Medica Hospitalia : Journal of Clinical Medicine, 2(2). https://doi.org/10.36408/mhjcm.v2i2.102 